\title{
MITIGATION OF SCOUR FAILURE RISK OF A RIVER BRIDGE LOCATED IN AN UNGAUGED BASIN
}

\section{HÜSEYIN AKAY* \\ Civil Engineering Department, Gazi University, Ankara, Turkey}

Received 23 October 2019; accepted 9 October 2020

\begin{abstract}
In this study, scour failure risk of the Çatalzeytin Bridge located in the Western Black Sea Basin, Turkey, was assessed for possible future flood events and appropriate scour countermeasures were considered based on economic and constructability considerations. Waterway adequacy in the spans of the bridge and scour criticality around bridge foundations considered for risk calculations in HYRISK were estimated by hydrological and hydraulic analyses of the watershed and stream. Since the watershed of the bridge is ungauged, geomorphological instantaneous unit hydrograph concept was adopted to estimate the peak discharges with various return periods to be used in hydraulic modelling. Monte Carlo simulation results indicated that most of the simulated peak discharges were in the 95\% confidence interval. Hydraulic model results from HECRAS indicated that waterway adequacy and scour criticality were critical for discharges with 200 and 500-year return periods. Scour failure risk of the Çatalzeytin Bridge was classified as high and it was proposed to reduce the risk by constructing partially grouted riprap as the most feasible alternative that would consequently increase the expected lifespan of the bridge. Following this methodology, river bridges may be prioritized based on the risk analysis.
\end{abstract}

Keywords: GIUH, HYRISK, scour criticality, ungauged basin, waterway adequacy, Western Black Sea Basin.

\footnotetext{
* Corresponding author. E-mail: akayhsyn@gmail.com

Hüseyin AKAY (ORCID ID 0000-0002-9714-4590)

Copyright (C) 2021 The Author(s). Published by RTU Press

This is an Open Access article distributed under the terms of the Creative Commons Attribution License (http://creativecommons.org/licenses/by/4.0/), which permits unrestricted use, distribution, and reproduction in any medium, provided the original author and source are credited.
} 


\section{Introduction}

Scour criticality and waterway adequacy are the key input parameters to assess scour failure risk and expected age of a bridge computed using HYRISK software developed by the Federal Highway Administration (FHwA). Johnson and Whittington (2011) assessed cost vulnerability for Level 2 assessment of a river bridge in terms of stability of stream, channel condition, waterway adequacy and scour criticality. Hence, scour criticality and waterway adequacy items used in HYRISK must be rigorously determined and scour countermeasures must be designed, accordingly. However, waterway adequacy in the spans of a river bridge and scour criticality around bridge foundations may not be examined adequately, particularly for old bridges, due to the lack of stream data and gauging stations. In Turkey, specifically river bridges located on steep streams, which collect water from small watersheds, suffer from the lack of stream discharge data due to the limited number of gauging stations. In recent years, an increasing number of river bridges in the northern part of Turkey with steep-slope, small and ungauged watersheds have been damaged or have failed due to the flash floods as a result of changes in watershed characteristics and precipitation pattern. Furthermore, possible changes in climatic and environmental factors, river or land use in the watershed may alter the safety of river bridges in time, thereby increasing the need for performing non-stationary ensemble models.

As floods threaten the serviceability of river bridges, their safety must be assured under different flood events with varying return periods $\left(T_{\mathrm{r}}\right)$. Hence, scour criticality and waterway adequacy in the spans of a bridge under various flood conditions must be examined using the available data and scientific approaches. Possible future flood discharges for ungauged basins can be estimated by transferring, regionalizing hydrologic parameters from gauged neighbouring basins or remote sensing and field measurement techniques. However, it is not recommended to use transferred or spatially distributed hydrologic parameters in the computation of design discharge as the spatial heterogeneities in the considered watershed may not be captured (Akay, Baduna Koçyiğit, \& Yanmaz, 2018; Baduna Koçyiğit \& Akay 2018; Baduna Koçyiğit, Akay, \& Yanmaz, 2017; Zhang et al., 2013). Unit hydrograph of a watershed can also be estimated using morphometric parameters, which can directly reflect the characteristics of a watershed. For this, geomorphological instantaneous unit hydrograph (GIUH) concept is considered to be successful and has been validated for many basins all over the world (Ghumman, Al-Salamah, Alsaleem, \& Haider, 2017; Kumar, 
Chatterjee, Singh, Lohani, \& Kumar, 2007; Rodriguez-Iturbe \& Valdes, 1979; Sahoo, Chatterjee, Raghuwanshi, Singh, \& Kumar, 2006). GIUHensemble hydrologic models, whose estimated results are validated using the data of nearby gauged basins, may contribute to further understanding of the response of an ungauged basin.

Scour failure risk can be mitigated by constructing an appropriate countermeasure at the point before the bed lowers towards the footings. Johnson and Niezgoda (2004) proposed appropriate countermeasures suggesting the risk-based priority number method based on failure modes and effects analysis. Lagasse et al. (2007) also introduced detailed design procedures of various scour countermeasures. Yanmaz and Apaydin (2012) assessed scour failure risks under possible future conditions, designed some scour countermeasures and selected the most appropriate and feasible one.

In this study, scour failure risk assessment of the Çatalzeytin Bridge, whose watershed is ungauged, was performed using HYRISK software. Necessary peak discharges with different return periods were transformed from effective precipitation using GIUH approach. Then, Monte Carlo simulation was used to test whether those values were in the $95 \%$ confidence interval. Scour criticality and waterway adequacy were estimated by HECRAS using estimated peak discharges. Some of the input parameters used in HYRISK were estimated in the course of hydrologic and hydraulic analyses, and field trips. Finally, various types of scour countermeasures were designed and economically assessed.

\section{Materials and methods}

\subsection{Study area}

The Çatalzeytin Bridge located in the Western Black Sea Basin is the only route that connects two counties. It was opened to traffic in 1963. It was designed as Gerber beam with two piers skewed to the flow. In 1988, one of the piers of the bridge was damaged due to flood and then was reconditioned (Akay \& Baduna Koçyiğit, 2020; Akay, Baduna Kocyigit, \& Yanmaz, 2019). However, in recent years, the width of the stream bed was significantly reduced to expand a route parallel to the stream. So, stream levees were constructed at both banks of the stream. This is thought to increase the risk that the Çatalzeytin Bridge might face during flooding. During this study, the Çatalzeytin Bridge was inspected ten times in three years at different flow conditions. During inspections, it was noticed that excessive scour around bridge foundations occurred and the tops of bridge 
foundations were visible. Furthermore, some inputs used in risk analysis, such as channel protection and substructure conditions, were recorded.

The Akçay Stream, which flows through the bridge, collects water from $372.4 \mathrm{~km}^{2}$ drainage area and drains water into Black Sea, just downstream of the bridge. The watershed has dominantly forested, steep mountains with maximum, median and minimum altitudes of $2005 \mathrm{~m}, 1150 \mathrm{~m}$, and $7 \mathrm{~m}$, respectively, with an average slope of $45 \%$. The watershed may take heavy rainfall in a year with heavy snow, especially at high altitudes. Curve number of the watershed was estimated as 79.3 considering the land cover/use and hydrologic soil group distributions in the watershed. Considering the curve number, it can be pointed out that large amount of that precipitation transforms into runoff.

\subsection{Methodology}

Methodology followed in this study is demonstrated in the flowchart given in Figure 1. The main steps of the methodology include GIUH ensemble hydrologic modelling, Monte Carlo simulation and uncertainty

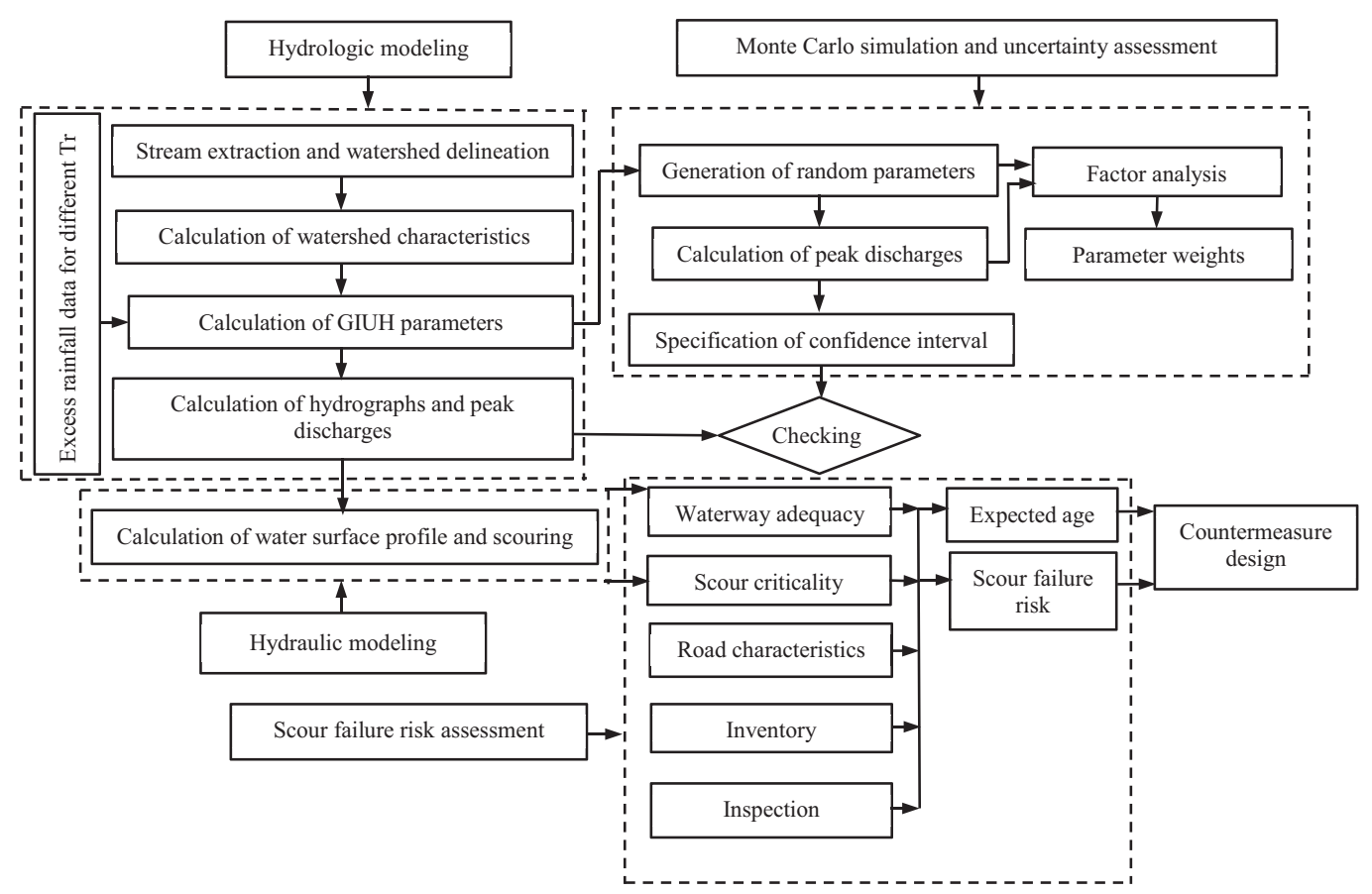

Figure 1. Flowchart of the methodology to assess the scour failure risk of the Çatalzeytin Bridge 
assessment of GIUH parameters, hydraulic modelling, scour failure risk, and countermeasure design. Details of the main steps are given in the following sections.

\subsection{Hydrologic modelling}

Since there are no available stream gauging stations on the Akçay Stream and the frequency analysis of the stream cannot be directly determined, hydrologic analysis has been performed to estimate the peak flow discharge for different return periods. Hydrologic parameters for ungauged basins could be directly transferred, regionalized from the gauged neighbouring basins or determined by remote-sensing and field measurements. However, hydrologic parameters used in these hydrological processes may not be efficiently estimated and those methods may not reflect the topographic heterogeneities in the ungauged basins. Hence, a reliable method for the estimation of hydrological processes should be adopted in order to estimate the flood hydrographs.

Analysis of hydrologic processes was conducted using meteorological and basin model components. Precipitation data of intensity duration frequency (IDF) curve with return periods of 2 , $5,10,25,50,100,200$ and 500 years observed at the Çatalzeytin Meteorological Observation Station were used in the meteorological model. In the basin model, excess rainfall and transformation of that rainfall to runoff were modelled using SCS-CN method and unit hydrograph approach, respectively. The SCS-CN method can estimate all kinds of losses and effective rainfall $(E R)$ in the watershed, as given in Eqs. (1) and (2):

$$
\begin{aligned}
& E R(t)=\frac{\left(P-I_{\mathrm{a}}\right)^{2}}{P-I_{\mathrm{a}}+S_{\mathrm{s}}}, \\
& S_{\mathrm{s}}=\frac{25400}{C N}-254,
\end{aligned}
$$

where $I_{\mathrm{a}}$ - initial abstraction; $P$ - precipitation; $S_{\mathrm{s}}$ - potential maximum retention in soil, $\mathrm{mm}$; and $C N$ - curve number of the watershed. $I_{\mathrm{a}}$ value depends on the moisture of the soil and can generally be defined as 0.2 times of $S_{\mathrm{s}}$ assuming the soil is in dry conditions.

Direct runoff hydrographs corresponding to any return periods were transformed from ER values using Nash's geomorphological instantaneous hydrograph (GIUH) concept, since it was found to perform very good in estimation of direct runoff hydrograph at close watershed of the Akçay Basin (Akay, 2019). GIUH ordinates were calculated considering the geomorphological characteristics of the watershed 
and the following procedure was followed to estimate the watershed characteristics.

Digital elevation model (DEM) and flow accumulation (Fac), with $10 \mathrm{~m}$ resolution of the watershed of the Chatalzeytin Bridge sited at the outlet of the watershed, were generated in ArcGIS 10.1 using the 1:25000 scaled topographic maps. Stream network was extracted by taking the threshold value of Fac as 100 since it was determined to be sensitive for prioritization of the watershed with regard to flash floods (Baduna Koçyiğit \& Akay, 2018). Stream orders were designated using Strahler (1957) method, as shown in (Figure 2). After discrete streams having the same order that were greater than one were merged manually, the weighted dominant morphometric parameters such as length ratio, bifurcation ratio and area ratio parameters were computed and used for calculation of GIUH ordinates. Design storm hydrographs and flood peak discharges with return periods of 2, 5, 10, 25, 50, 100, 200, and 500 years, which may potentially flow through the Çatalzeytin Bridge, were determined to estimate the waterway adequacy and scour criticality around bridge foundations.

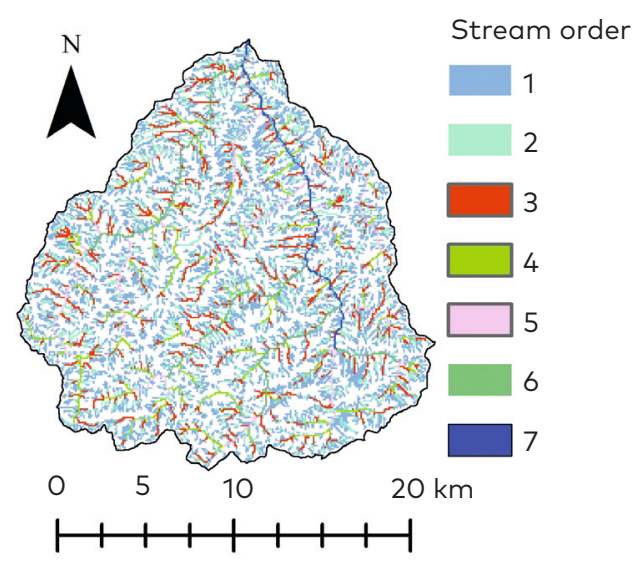

Figure 2. Stream orders of the watershed of the Catalzeytin Bridge

\subsection{Nash's instantaneous unit hydrograph}

The Nash's instantaneous unit hydrograph concept assuming twoparameter gamma distribution $(\Gamma)$ considers $n$ numbers of successive linear reservoirs having the same storage coefficients $(k)$, as given in Eq. (3). 
where $u(t)$ - ordinate of the hydrograph at time $t, \mathrm{~h}^{-1}$; and $\Gamma$ - gamma function. Rosso (1984) proposed Eqs. (4) and (5) to estimate simply $k$ and $n$ values of a watershed without solving non-linear iterations. Moreover, $\Gamma$ values may be approximated in terms of $n$ by Eq. (6) proposed by Nemes (2010).

$$
\begin{gathered}
n=3.29\left(\frac{R_{\mathrm{b}}}{R_{\mathrm{A}}}\right)^{0.78} R_{\mathrm{l}}^{0.07} ; \\
k=0.70\left(\frac{R_{\mathrm{A}}}{R_{\mathrm{b}} R_{\mathrm{l}}}\right)^{0.48} \frac{L_{\Omega}}{v} ; \\
\Gamma=\left(\frac{n}{\mathrm{e}}\right)^{n} \sqrt{\frac{2 \pi}{n}}\left(1+\frac{1}{12 n^{2}-0.1}\right)^{n},
\end{gathered}
$$

where $R_{\mathrm{b}}$ - bifurcation ratio; $R_{\mathrm{A}}$ - area ratio; $R_{\mathrm{l}}$ - length ratio; $L_{\Omega}$ - main channel length, km; $v$ - velocity of peak flood discharge $\left(Q_{\mathrm{p}}\right), \mathrm{m} / \mathrm{s}$; and e natural logarithm constant. $R_{\mathrm{b}}, R_{\mathrm{A}}, R_{\mathrm{l}}$, and $L_{\Omega}$ values of the watershed of the Çatalzeytin Bridge were estimated by ArcGIS 10.1, while $n, k$ and $\Gamma$ values were computed from Eqs. (4)-(6).

There are various approaches for estimation of the $v$ value that considers watershed characteristics and excess rainfall depths (Chen et al., 2019; Ghumman et al., 2017; Gupta, Waymire, \& Wang, 1980, Hosseini, Mahjouri, \& Riahi, 2016; Rodriguez-Iturbe, Gonzalez-Sanabria, \& Bras, 1982; Sahoo et al., 2006). Sahoo et al. (2006) proposed a stepfunction relationship between excess rainfall intensity and flow velocity. Kumar et al. (2007) adopted the peak velocity as $2.5 \mathrm{~m} / \mathrm{s}$ based on the field measurements in their study. Hosseini et al. (2016) adopted the main channel length and watershed slope, while Ghumman et al. (2017) considered the excess rainfall, drainage area and kinematic wave parameter of the channel to estimate the expected peak velocity. On the other hand, Chen et al. (2019) proposed a new method to estimate the dynamic-factor peak velocity considering the extraction of geomorphologic characteristics of the watershed using random forest technique. In most of the similar studies, the peak velocity was calculated as $2.0-2.5 \mathrm{~m} / \mathrm{s}$, so in this study the peak velocity was taken as $2.5 \mathrm{~m} / \mathrm{s}$, as recommended by Kumar et al. (2007).

Calculated parameters to estimate the ordinates of GIUH of the watershed of the Çatalzeytin Bridge are given in Table 1. Since parameters given in Table 1 may have uncertainties, those uncertainties might directly affect the model outputs. So, Monte Carlo simulation, 
Table 1. Computed parameters to estimate GIUH ordinates

\begin{tabular}{ccccccccc}
\hline $\boldsymbol{R}_{\mathbf{I}}$ & $\boldsymbol{R}_{\mathbf{b}}$ & $\boldsymbol{R}_{\mathbf{A}}$ & $\boldsymbol{L}_{\Omega}$ & $\boldsymbol{v}$ & $\boldsymbol{n}$ & $\boldsymbol{k}$ & $\boldsymbol{\Gamma}$ & $\boldsymbol{C N}$ \\
\hline 4.74 & 2.05 & 4.95 & 21.92 & 2.5 & 3.35 & 4.44 & 2.82 & 79.3 \\
\hline
\end{tabular}

which is one of the stochastic approaches, was implemented coupled with the hydrologic model to investigate the uncertainty and factor analysis of the impact of each parameter on model outputs and the usability of specified parameters.

\subsection{Monte Carlo simulations}

Monte Carlo simulations coupled with the hydrological processes are based on the random number generation of effective parameters of GIUH and implementation of the hydrological model. Monte Carlo simulations were performed to examine the uncertainty assessment and factor analysis of the impact of each generated parameter on the calculated peak discharges. Hence, random variables such as $R_{\mathrm{b}}, R_{\mathrm{A}}, R_{\mathrm{l}}, L_{\Omega}, v$, and $C N$ which have effects on the model outputs were generated with 1000 runs assuming normal distribution due to its simplicity. $R_{\mathrm{b}}, R_{\mathrm{A}}, R_{\mathrm{l}}$, and $L_{\Omega}$ values are sensitive to the scale effect of stream network caused by the threshold value of Fac and vary in a narrow range. $C N$ value of the watershed may be affected by the initial moisture of the soil and errors in the land use/cover and soil maps. $v$ value is the velocity of the peak discharge as a consequence of excess rainfall and watershed characteristics (Sahoo et al., 2006). $v$ value may vary in a large range depending on the local channel properties. The calculated parameters given in Table 1 were assumed as averages of the generated random variables. Coefficient of variance (COV) was assigned the value of 0.1 for $v$ parameter, while COV values of other parameters were assigned the value of 0.05 , as mentioned before. Although $\mathrm{COV}$ for $\mathrm{CN}$ was taken at a low value, random $C N$ values varied in a large range, which might describe the soil moisture conditions at different saturation levels that reflect the real case condition. It should be noted that a COV value of simulated peak discharges is an important indicator of uncertainty. As the COV values of simulated results increase, uncertainty also increases.

The ordinates of the GIUH were first calculated and then the peak discharges were simulated using generated random parameter values for each run and $T_{\mathrm{r}}$. Moreover, 95\% upper and lower limits of confidence interval of the simulated peak discharges for different $T_{\mathrm{r}}$ were determined. Computed peak discharges using average values of parameters corresponding to $T_{\mathrm{r}}$ were tested by simulation 
Table 2. Computed peak discharges from average and generated values, confidence intervals and $\mathrm{COV}$ values of peak discharges for $2,5,10,25,50,100,200$ and 500-year return periods

\begin{tabular}{r|rrrrrrrrr}
\hline \multirow{2}{*}{$Q_{p}$} & $\boldsymbol{T}_{\text {r, } \text { years }}$ & $\mathbf{2}$ & $\mathbf{5}$ & $\mathbf{1 0}$ & $\mathbf{2 5}$ & $\mathbf{5 0}$ & $\mathbf{1 0 0}$ & $\mathbf{2 0 0}$ & \multicolumn{1}{c}{$\mathbf{5 0 0}$} \\
\cline { 2 - 10 } & Average (Table 1) & 31.3 & 71.9 & 107.1 & 160.4 & 207.0 & 259.2 & 370.0 & 520.8 \\
\cline { 2 - 9 } & $95 \%$ upper limit & 33.8 & 74.9 & 110.4 & 164.2 & 210.7 & 262.8 & 373.5 & 524.7 \\
\cline { 2 - 10 } & $95 \%$ lower limit & 32.1 & 72.1 & 106.8 & 159.7 & 205.6 & 257.0 & 366.4 & 516.0 \\
\cline { 2 - 10 } & COV & 0.44 & 0.31 & 0.26 & 0.22 & 0.20 & 0.18 & 0.15 & 0.13 \\
\hline
\end{tabular}

of parameters obtained from Monte Carlo results (Table 2). Peak discharges computed from the average values were found to be in the 95\% confidence interval with the results obtained from Monte Carlo simulations except for the discharges of $T_{\mathrm{r}}$ of 2 and 5 years. COV values computed from Monte Carlo simulations decreased as $T_{\mathrm{r}}$ increased. This is an important indicator that COV of computed peak discharges vary in a large range which means a decrease in uncertainty as $T_{\mathrm{r}}$ increases. This is an important finding, since peak discharges with higher $T_{\mathrm{r}}$ values may be critical for assessment of waterway adequacy and scour criticality. Moreover, it can be concluded that peak discharges for $T_{\mathrm{r}}$ of 2 and 5 years were not critical in terms of waterway adequacy and scour criticality, peak discharges computed from average parameter values were found to be reasonable to be used in the hydraulic analysis.

Factor analysis based on the eigenvalues of parameters extracted by principal component analysis in SPSS was also conducted using the

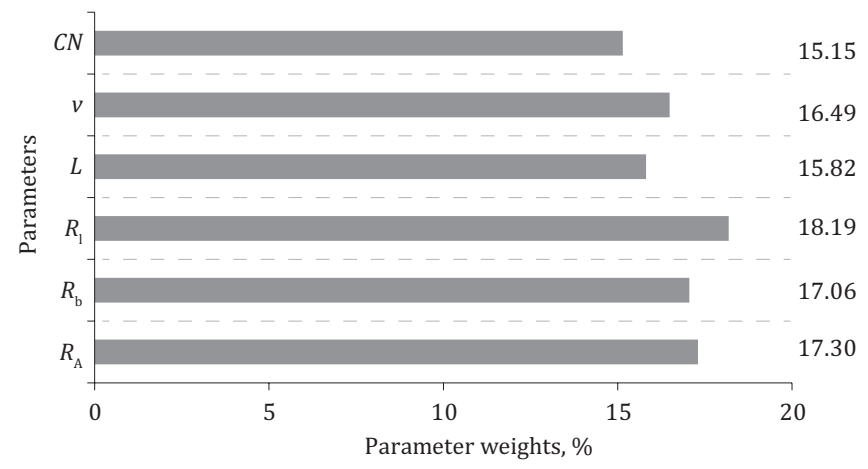

Figure 3. Factor analysis results indicating the weights of parameters obtained from cross-correlation analysis 
generated GIUH parameters to investigate the contribution of each parameter. It is noted that the contributions of parameters become close varying between $15-19 \%$, since each parameter has initial eigenvalues close to each other. Weights of each parameter were simplified by using the cross-correlation analysis of parameters obtained from factor analysis adopted by Malik et al. (2019). Figure 3 represents parameter weights in percent from factor analysis. $R_{1}$ had the maximum weight, while $C N$ had the minimum weight.

\subsection{Hydraulic modelling}

In this study, hydraulic computations were performed by HECRAS model which is a free software developed by US Army Corps of Engineers, Hydrologic Engineering Centre. HECRAS is used to analyse both one- and two-dimensional hydraulic calculations including steady and unsteady flow simulations, sediment transport computations, and water quality analysis (HEC, 2010). All computations performed by HECRAS require entry of geometric data of the channel and flow either manually or importing. Geometric input data, such as stream cross-sections at desired stations, location and dimensions of control structures, and roughness values at cross-section, as well as flow data at boundary conditions can be entered.

Inspection studies enabled surveying of the alignment and crosssections of the stream, and geometric properties of the Çatalzeytin Bridge were used in hydraulic computations. Flood peak discharges obtained from hydrologic modelling coupled with Monte Carlo simulation and factor analysis for different $T_{\mathrm{r}}$ were also used in hydraulic computations of steady state flow data. Running the model, water surface profile along the cross-sections of reach and in the spans of the bridge was computed. Moreover, scouring at bridge piers and abutments in terms of dimensions of pier, abutment, and bed material size and conditions was computed by Colorado State University (CSU) and Froehlich equations, respectively. According to the hydraulic model results, bridge was found to be submerged for peak discharge having $T_{\mathrm{r}}$ of 200 years and more. Moreover, calculations showed that the piers of the Chatalzeytin Bridge were unstable due to the excessive scouring with a peak discharge having $T_{\mathrm{r}}$ of 200 years and more. Waterway adequacy in the spans and scour criticality around bridge foundations that was used to estimate the scour failure risk of Çatalzeytin Bridge were estimated by combining the hydraulic model results and scour risk assessment criteria defined by Pearson et al. (2002). 
HYRISK software developed by FHwA was used for scour failure risk assessment of the Çatalzeytin Bridge for possible future peak discharges. HYRISK implements a qualitative risk analysis of scour induced failure that is the product of failure probability and its consequences (Pearson et al., 2002). Failure probability in US dollars is considered as a function of overtopping frequency and scour criticality, while the consequences of failure are considered as the summation of rebuilding and running of the bridge, and time costs. The economic feasibility of any available scour countermeasures at a particular bridge site can be evaluated based on the cost analysis associated with loss of life and, knowing the service life of the structure, the time value of money, in the scour countermeasures calculator provided in HYRISK (Pearson et al., 2002). So, the cost-benefit relation can be analysed for any countermeasure structure. Annual scour risk $(R)$ of a river bridge in US dollars, which is composed of rebuilding, running and time costs, can be computed by Eq. (7).

$$
R=K P_{\mathrm{A}}\left[C_{1} W L_{\mathrm{b}} M+C_{2} D A d+\left[C_{3} O\left(1-\frac{T}{100}\right)+C_{4} \frac{T}{100}\right] \frac{D A d}{S}\right],
$$

where $K$-risk adjustment factor; $P_{\mathrm{A}}$ - annual probability of scour failure, 1 /year; $C_{1}$ - unit rebuilding cost, US $\$ / \mathrm{m}^{2} ; W$ - bridge deck width, $\mathrm{m} ; L_{\mathrm{b}}$ - bridge length, $\mathrm{m} ; M$ - cost multiplier to replace bridge after the scour failure; $C_{2}$ - unit cost of running vehicle, US\$/km; $D$ - detour length, km; $A$ - average daily traffic, vehicles per day; $d$ duration of detouring, days; $C_{3}$ - unit value of time per adult, US $\$ / \mathrm{h}$; $O$-occupancy rate, adults per vehicle; $T$ - average daily truck traffic of $A, \% ; C_{4}-$ unit value of time per truck, US $\$ / \mathrm{h}$; and $S$ - average detour speed, km/h (Pearson et al., 2002).

Some input parameters, such as the year of built, functional class of the bridge, bypass length, average daily traffic $(A)$, truck traffic per cent of $A$, service type, construction type, structural design, deck width, and structural length, were provided by the authorities that are in charge of the construction, maintenance, and running of highways and bridges. Current conditions of the substructure and channel protection were inspected during field studies. Inspections at different time intervals showed that excessive scour, which occurred around bridge foundations, could be visually observed. Since levees at both sides of the channel were constructed, it was concluded that the banks were protected. Hence, the substructure was coded as 4 , which indicated poor conditions, and channel protection was coded as 8 . 
As mentioned before, one of the most important parameters $P_{\mathrm{A}}$ is a function of waterway adequacy in the spans of the bridge, as well as the scour criticality around the foundations. Hydraulic modelling simulation results as the product of hydrologic modelling coupled with Monte Carlo analysis and factor analysis of GIUH parameters, enabled to estimate at which level water may approach to the bridge girders and scouring depth at bridge foundation. Waterway adequacy was coded in HYRISK according to both the hydraulic modelling simulation results and the National Bridge Inventory (NBI) Item 71 descriptions. Similarly, scour criticality was coded according to the scour calculations performed by HECRAS and the stability of bridge foundation due to scouring described in NBI Item 113 (Pearson et al., 2002). So, $P_{\mathrm{A}}$ was calculated accordingly.

For some parameters and coefficients, default values stored in the software recommended by AASHTO were used for calculation of $R$, especially for the components of time cost parameters. The 90th percentile mean time to scour failure $\left(X_{90}\right)$, which is the expected remaining service life of a river bridge, can be approximated by Eq. (8).

$$
X_{90}=\frac{\log (1-0.90)}{\log \left(1-P_{\mathrm{TR}}\right)},
$$

where $P_{\mathrm{TR}}$ represents trial probability of scour failure assuming binomial distribution (Pearson et al., 2002). Table 3 presents the codes of waterway adequacy and scour criticality for various $T_{\mathrm{r}}$, and thus, the calculated scour failure risk and expected ages, accordingly.

Rebuilding, running, and time costs for the Çatalzeytin Bridge were independent of $T_{\mathrm{r}}$, waterway adequacy, and scour criticality, and were found to be US\$ 329 858, US\$ 1320543 and US\$ 2518 540, respectively. Annual scour failure risk $R$ for $T_{\mathrm{r}}$ of 2 years was US\$ 14580 per year, while

Table 3. Scour failure risks and expected ages of the Çatalzeytin Bridge for various $T_{\mathrm{r}}$

\begin{tabular}{rcccccc}
\hline$T_{\text {rr }}$ years & $\begin{array}{c}\text { Waterway } \\
\text { adequacy }\end{array}$ & $\begin{array}{c}\text { Scour } \\
\text { criticality }\end{array}$ & $\boldsymbol{P}_{\mathrm{TR}}$ & $\boldsymbol{P}_{\mathrm{A}}$ & $\boldsymbol{R}_{\boldsymbol{r}}$ US\$ per year & $\begin{array}{c}\text { Expected age, } \\
\text { years }\end{array}$ \\
\hline 2 & 9 & 5 & 0.005 & 0.005 & 14580 & 440 \\
\hline 5 & 9 & 4 & 0.127 & 0.041 & 114523 & 17.0 \\
\hline 10 & 9 & 4 & 0.127 & 0.041 & 114523 & 17.0 \\
\hline 25 & 9 & 4 & 0.127 & 0.041 & 114523 & 17.0 \\
\hline 50 & 8 & 4 & 0.137 & 0.041 & 114523 & 15.6 \\
\hline 100 & 5 & 4 & 0.228 & 0.041 & 114523 & 8.9 \\
\hline 500 & 3 & 3 & 0.398 & 0.041 & 114523 & 4.5 \\
\hline 50 & 2 & 3 & 0.495 & 0.041 & 114523 & 3.4 \\
\hline
\end{tabular}


$R$ was US\$ 114523 per year for the rest of $T_{\mathrm{r}}$, since $P_{\mathrm{A}}$ did not change with respect to $T_{\mathrm{r}}$. However, the change in $P_{\mathrm{TR}}$ inversely altered the expected age of the river bridge. The expected lifespan is 17 years, if a 5-year recurrence flood passes through the spans of the Çatalzeytin Bridge. However, the expected lifespan of the Çatalzeytin Bridge is 3.4 years is case of a flood with 500-year return period that causes significant delay in traffic and serious damage to the infrastructure. Annual scour failure risks of bridges in the USA are classified as acceptable risk at US\$1000 per year, medium risk at US\$10 000 per year, and unacceptable risk at US\$100 000 per year (Briaud, Gardoni, \& Yao, 2012). Hence, an appropriate countermeasure against scouring should be installed around bridge foundations of the Çatalzeytin Bridge to prevent serious damage or failure of the bridge due to possible extreme flood events, since the scour failure risk is estimated as high for the Çatalzeytin Bridge.

\subsection{Risk mitigation and countermeasure design}

Calculations showed that piers of the Çatalzeytin Bridge were unstable when peak discharge of the flood with 200 years and more recurrence peak discharge passed through the bridge. In case of installing scour countermeasure around foundations of the Çatalzeytin Bridge, scour criticality was coded as 8 in HYRISK indicating that the foundations were stable (Pearson et al., 2002; Yanmaz \& Apaydin, 2012). Thus, annual scour failure risks for 200 and 500-year recurrence floods then decreased to US\$ 40222 per year and US\$ 77762 per year and expected ages increased to 158.7 and 81.6 years, respectively. Moreover, Yanmaz and Apaydin (2012) compared the benefits of the bridge countermeasures, such as partially grouted riprap, grout filled bag and gabion box. In this study, when the riprap was considered as a countermeasure, the depth of the riprap under the subgrade level was found to be very large and piers were unstable. So, partially grouted riprap, grout filled bag and gabion box were considered to mitigate scour failure risk.

\subsection{Partially grouted riprap}

As rocks are glued by grouts, rock classification, amount and grout volume should be determined in case of installation of partially grouted riprap (Lagasse et al., 2007). Since the median size of $6 \mathrm{~cm}$ of the classical riprap was acceptable, Class I with median riprap size of $16 \mathrm{~cm}$, void ratio of $50 \%$, porosity of $35 \%$ and specific gravity of 2.65 were selected for design of partially grouted riprap. As the tops of pier foundations of the Çatalzeytin Bridge were visible, $2 \mathrm{~m}$ soil was 
Table 4. Unit prices and costs of partially grouted riprap

\begin{tabular}{lcccc}
\hline \multicolumn{1}{c}{ Work package } & Unit & $\begin{array}{c}\text { Unit price, } \\
\text { US\$ }\end{array}$ & Quantity & Cost, US\$ \\
\hline Excavation & $\mathrm{m}^{3}$ & 7.2000 & 126.00 & 907.20 \\
\hline Transportation of excavation & $\mathrm{t}$ & 0.6415 & 333.50 & 213.94 \\
\hline Grout & $\mathrm{m}^{3}$ & 45.0736 & 22.05 & 993.87 \\
\hline Riprap & $\mathrm{m}^{3}$ & 5.9962 & 81.90 & 491.09 \\
\hline Transportation of riprap & $\mathrm{m}^{3}$ & 1.1830 & 126.00 & 149.06 \\
\hline Geotextile and its placement & $\mathrm{m}^{2}$ & 0.9340 & 38.00 & 35.49 \\
\hline Total cost & & & & 2790.66 \\
\hline Total cost with contingencies & & & & 3209.26 \\
\hline
\end{tabular}

excavated from the channel bed to the bottom elevation of the pier foundation. Thus, $1.5 \mathrm{~m}$ was excavated, which was greater than two times of pier width of $1.2 \mathrm{~m}$, and covered by soil from each outer edge of the circumference of the bridge pier foundations (Lagasse et al., 2007). Partially grouted riprap was placed to the excavated lands. Excavation and manufacturing of partially grouted riprap were performed according to these requirements. Geotextile filter was placed extending two thirds of the distance where riprap was stretched. Grout volume was determined by multiplication of the excavation volume, void ratio and porosity. Riprap volume is the volume of the solid rock soil. $126 \mathrm{~m}^{3}$ soil samples were excavated and transported. $38 \mathrm{~m}^{2}$ geotextile was placed under partially grouted riprap. $81.90 \mathrm{~m}^{3}$ riprap and $22.05 \mathrm{~m}^{3}$ grout were needed to construct partially grouted riprap. The cost of each item of partially grouted riprap and contingencies of the total cost are given in Table 4. Contingency rate for all countermeasures was considered as $15 \%$ of the total cost (Yanmaz \& Apaydın, 2012).

\subsection{Grout filled bag}

Canvas bags filled with grout are used to armour the channel in the vicinity of bridge crossing (Yanmaz \& Apaydın, 2012). Canvas bags with dimensions of $1.2 \mathrm{~m} \times 0.9 \mathrm{~m} \times 0.3 \mathrm{~m}$ (length, width and thickness) as suggested by Ozdemir (2003) were used. For this, $1.8 \mathrm{~m}$ of soil depth between the lower foundation level and the top level of canvas bags and $2.4 \mathrm{~m}$ of soil depth around the circumference of each edge of pier foundations were excavated and transported. $212.55 \mathrm{~m}^{3}$ soil was excavated and $212.55 \mathrm{~m}^{3}$ grout was filled in 656 canvas bags and placed into the excavated lands. Costs of each item to be installed for grout filled bags are given in Table 5 . 
Table 5. Unit prices and costs of grout filled bags

\begin{tabular}{lccrr}
\hline \multicolumn{1}{c}{ Work package } & Unit & Unit price, US\$ & Quantity & Cost, US\$ \\
\hline Excavation & $\mathrm{m}^{3}$ & 7.2000 & 212.55 & 1530.36 \\
\hline Transportation of excavation & $\mathrm{t}$ & 0.6415 & 563.26 & 361.34 \\
\hline Grout & $\mathrm{m}^{3}$ & 45.0736 & 212.55 & 9580.39 \\
\hline Canvas & $\mathrm{m}^{2}$ & 1.0283 & 2243.52 & 2307.02 \\
\hline Total cost & & & & 13779.10 \\
\hline Total cost with contingencies & & & & 15845.97 \\
\hline
\end{tabular}

\subsection{Gabion box}

Gabion boxes can be used in many fields including scour countermeasures. Riprap with graded sizes is placed into gabion boxes with varying permeable mesh sizes and the channel bed is protected by the armouring effect. In the study, $2 \mathrm{~m}$ of soil depth between the lower foundation level and the channel bed and $2 \mathrm{~m}$ of soil depth around the circumference of the pier foundations were excavated. Geotextile was placed under the gabion boxes, its dimensions were $2.0 \mathrm{~m} \times 1.0 \mathrm{~m} \times 1.0 \mathrm{~m}$ and $2.0 \mathrm{~m} \times 1.0 \mathrm{~m} \times 0.5 \mathrm{~m}$, where necessary, and filled with graded riprap. $184 \mathrm{~m}^{3}$ of soil was excavated and transported. $92 \mathrm{~m}^{2}$ geotextile was placed under the gabion boxes. 80 of $2.0 \mathrm{~m} \times 1.0 \mathrm{~m} \times 1.0 \mathrm{~m}$ and 24 of $2.0 \mathrm{~m} \times$ $1.0 \mathrm{~m} \times 0.5 \mathrm{~m}$ gabion boxes were filled in with $184 \mathrm{~m}^{3}$ graded riprap. Costs of each item to be installed for the gabion box are given in Table 6.

Table 6. Unit prices and costs of the gabion box

\begin{tabular}{lccrc}
\hline \multicolumn{1}{c}{ Work package } & Unit & Unit price, US\$ & Quantity & Cost, US\$ \\
\hline Excavation & $\mathrm{m}^{3}$ & 7.2000 & 184.00 & 1324.80 \\
\hline Transportation of excavation & $\mathrm{t}$ & 0.6415 & 487.60 & 312.80 \\
\hline $2.0 \mathrm{~m} \times 1.0 \mathrm{~m} \times 1.0 \mathrm{~m}$ gabion box & piece & 35.4868 & 80 & 2838.94 \\
\hline $2.0 \mathrm{~m} \times 1.0 \mathrm{~m} \times 0.5 \mathrm{~m}$ gabion box & piece & 28.4868 & 24 & 683.68 \\
\hline Transportation of riprap & $\mathrm{m}^{3}$ & 1.1830 & 184.00 & 217.68 \\
\hline Geotextile and its placement & $\mathrm{m}^{2}$ & 0.9340 & 92.00 & 85.92 \\
\hline Total cost & & & & 5463.83 \\
\hline Total cost with contingencies & & & & 6283.40 \\
\hline
\end{tabular}




\section{Results and discussions}

Since US\$ 114520 per year annual scour risk was classified as high and the Çatalzeytin Bridge would continue to be in service for the next 50 years or more, three different scour countermeasures for the Çatalzeytin Bridge were analysed for 200 and 500-year recurrence floods (Pearson et al., 2002). These were partially grouted riprap, grout filled bags and gabion box with 15\% contingencies costing US\$3209.26, US\$ 15845.97 and US\$ 6283.40, respectively. According to the HYRISK results, as the scour criticality code was updated as 8 , the expected ages of the Chatalzeytin Bridge increased and the annual scour risk decreased. The corresponding category was changed after installation of the appropriate scour countermeasure. Net benefits of the construction of partially grouted riprap, grout filled bags and gabion box for the 50-year return period were calculated as US\$ 2724 241, US\$ 2711604 , US\$ 2721 167, respectively, and partially grouted riprap was found to be the most feasible alternative among other countermeasure options.

\section{Conclusions}

In this study, scour failure risk of the Çatalzeytin Bridge located in the Western Black Sea Basin was investigated for flash floods with 2, 5, 10, 25, 50, 100, 200 and 500-year return periods. The Akçay Creek flowing through the Çatalzeytin Bridge collects water from an ungauged basin. So, GIUH concept was used to estimate the peak discharges of the aforementioned return periods conducting analysis with some morphometric parameters computed for this concept. Next, the values of the computed morphometric parameters and curve number were taken as average values and then Monte Carlo simulation was used to generate 1000 random variables assuming a normal distribution for them. The hydrologic analysis indicated that although the peak discharges for $T_{\mathrm{r}}$ of 2 and 5 years were not in the limits of the $95 \%$ confidence interval and not critical for scour risk assessment of the Çatalzeytin Bridge for those $T_{\mathrm{r}}$ values, using computed peak discharges for the whole $T_{\mathrm{r}}$ in hydraulic modelling was found to be reasonable. According to the HECRAS results for $T_{\mathrm{r}}$ of 200 and 500 years during flooding, the Çatalzeytin Bridge was found to be submerged and scour criticality around bridge foundations was unstable. Since within this methodology it was significant to adopt 95\% lower and upper limits of peak discharges in hydraulic modelling, it would be beneficial to evaluate the sensitivity of both waterway adequacy and scour criticality of the Çatalzeytin Bridge in scour failure risk assessment. Scour failure risk was computed coding the relevant 
input in HYRISK for various $T_{\mathrm{r}}$. Risk was classified as high, so the scour countermeasure structure that would decrease the scour failure risk and increase the expected age was suggested. Conducting the economic analysis of three scour countermeasure structures, partially grouted riprap was found to be the most feasible one. It is believed that using this methodology, prioritization of river bridges, which are susceptible to flash floods and in which stream discharge values cannot be gauged, may be conducted regarding the results of economic analysis and considering the available budget of a responsible authority. Moreover, it is recommended to improve this methodology to account for the changing environmental, climatic, policy of run-of-river, and other factors in future.

\section{Funding}

This work was supported by the "Scientific and Technological Research Council of Turkey (TÜBİTAK)" under Grant [Project No: 114M292].

\section{REFERENCES}

Akay, H. (2019). Akım Ölçümü Olmayan Akarsular Üzerinde Yer Alan Köprülerin Göçme Riskinin Değerlendirilmesi. In Proceedings of the 4. Köprüler ve Viyadükler Sempozyumu (pp. 28-29). Turkey, Ankara. (in Turkish).

Akay, H., \& Baduna Koçyiğit, M. (2020). Hydrologic Assessment Approach for River Bridges in Western Black Sea Basin, Turkey. Journal of Performance of Constructed Facilities, 34(1), 04019090. https://doi.org/10.1061/(ASCE)CF.1943-5509.0001372

Akay, H., Baduna Koçyiğit, M., \& Yanmaz, A. M. (2018). Effect of Using Multiple Stream Gauging Stations on Calibration of Hydrologic Parameters and Estimation of Hydrograph of Ungauged Neighboring Basin. Arabian Journal of Geosciences, 11(11), 282. https://doi.org/10.1007/s12517-018-3642-z

Akay, H., Baduna Kocyigit, M., \& Yanmaz, A. M. (2019). Development of a Safety-Inspection Method for River Bridges in Turkey. Water, 11(9), 1902. https://doi.org/10.3390/w11091902

Baduna Koçyiğit, M., \& Akay, H. (2018). Estimation of Potential Flash Flood Risk in a Basin Using Morphometric Parameters: A Case Study of Akçay Basin. Journal of the Faculty of Engineering and Architecture of Gazi University, 33(4), 1321-1332. https://doi.org/10.17341/gazimmfd.416429

Baduna Koçyiğit, M., Akay H., \& Yanmaz, A. M. (2017). Effect of Watershed Partitioning on Hydrologic Parameters and Estimation of Hydrograph of an Ungauged Basin: A Case Study in Gokirmak and Kocanaz, Turkey. Arabian Journal of Geosciences, 10(15), 331.

https://doi.org/10.1007/s12517-017-3132-8 
Briaud, J. L., Gardoni, P. \& Yao, C. (2012). Bridge Scour Risk. In Proceedings of the 6 th International Conference on Scour and Erosion. Paris, France.

Chen, Y., Shi, P., Ji, X., Qu, S., Zhao, L., \& Dong, F. (2019). New Method to Calculate the Dynamic Factor-Flow Velocity in Geomorphologic Instantaneous Unit Hydrograph. Scientific Reports, 9(1), 14201.

https://doi.org/10.1038/s41598-019-50723-x

Ghumman, A. R., Al-Salamah, I. S., Alsaleem, S. S., \& Haider, H. (2017). Evaluating the Impact of Lower Resolutions of Digital Elevation Model on Rainfall-Runoff Modeling for Ungauged Catchments. Environmental Monitoring and Assessment, 189(2), 54. https://doi.org/10.1007/s10661-017-5766-0

Gupta, V., Waymire, E., \& Wang, C. (1980). A Representation of an Instantaneous Unit Hydrograph From Geomorphology. Water Resources Research, 16(5), 855-862. https://doi.org/10.1029/WR016i005p00855

HEC (Hydrologic Engineering Centre). (2010). HECRAS River Analysis System. HEC. U.S. $790 \mathrm{p}$.

Hosseini, S. M., Mahjouri, N., \& Riahi, S. (2016). Development of a Direct Geomorphologic IUH Model for Daily Runoff Estimation in Ungauged Watersheds. Journal of Hydrologic Engineering, 21(6), 05016008. https://doi.org/10.1061/(ASCE)HE.1943-5584.0001333

Johnson, P. A. \& Whittington, R. M. (2011). Vulnerability-Based Risk Assessment for Stream Instability at Bridges. Journal of Hydraulic Engineering, 137(10), 1248-1256. https://doi.org/10.1061/(ASCE)HY.1943-7900.0000443

Johnson, P. A., \& Niezgoda, S. L. (2004). Risk-Based Method for Selecting Bridge Scour Countermeasures. Journal of Hydraulic Engineering, 130(2), 121-128. https://doi.org/10.1061/(ASCE)0733-9429(2004)130:2(121)

Kumar, R., Chatterjee, C., Singh, R. D., Lohani, A. K., \& Kumar S. (2007). Runoff Estimation for an Ungauged Catchment Using Geomorphological Instantaneous Unit Hydrograph (GIUH) Models. Hydrological Processes, 21(14), 1829-1840. https://doi.org/10.1002/hyp.6318

Lagasse, P. F., Clopper, P. E., Zevenbergen, L. W., \& Girard, L. G. (2007). Countermeasures to protect bridge piers from scour. National Cooperative Highway Research Program Rep. No. 593. Transportation Research Board of the National Academies, Washington, DC.

Malik, A., Kumar, A., Kushwaha, D. P., Kisi, O., Salih, S. Q., Al-Ansari, N., \& Yaseen, Z. M. (2019). The Implementation of a Hybrid Model for Hilly Sub-Watershed Prioritization Using Morphometric Variables: Case Study in India. Water, 11, 1138. https://doi.org/10.3390/w11061138

Nemes, G. (2010). New Asymptotic Expansion for the Gamma Function. Archiv der Mathematik, 95(2), 161-169. https://doi.org/10.1007/s00013-010-0146-9

Ozdemir, C. E. (2003). A Feasibility Study on Bridge Scour Countermeasures (Dissertation, Middle East Technical University-Ankara).

Pearson, D., Stein, S., \& Jones, J. S. (2002). HYRISK Methodology and User Guide Federal Highway Administration Rep. No. FHWA-RD-02-XXX. Federal Highway Administration, Washington, DC.

Rodriguez-Iturbe, I., \& Valdes, J. (1979). The Geomorphologic Structure of Hydrologic Response. Water Resources Research, 15(6), 1409-1420.

https://doi.org/10.1029/WR015i006p01409 
Rodriguez-Iturbe, I., Gonzalez-Sanabria, M., \& Bras, R. (1982). A of a River Bridge Geomorphoclimatic Theory of the Instantaneous Unit Hydrograph. Water Resources Research, 18(4), 877-886. https://doi.org/10.1029/WR018i004p00877

Rosso, R. (1984). Nash Model Relation to Horton Order Ratios. Water Resources Research, 20(7), 914-920. https://doi.org/10.1029/WR020i007p00914

Sahoo, B., Chatterjee, C., Raghuwanshi, N. S., Singh, R., \& Kumar, R. (2006). Flood Estimation by GIUH Based Clark and Nash Models. Journal of Hydrologic Engineering, 11(6), 515-525. https://doi.org/10.1061/(ASCE)1084-0699(2006)11:6(515)

Strahler, A. N. (1957). Quantitative Analysis of Watershed Geomorphology. Transactions American Geophysical Union, 38(6), 913-920. https://doi.org/10.1029/TR038i006p00913

Yanmaz, A. M., \& Apaydin, M. (2012). Bridge Scour Risk Assessment and Countermeasure Design. Journal of Performance of Constructed Facilities, 26(4), 499-506. https://doi.org/10.1061/(ASCE)CF.1943-5509.0000254

Zhang, H. L., Wang, Y. J., Wang, Y. Q., Li, D. X., \& Wang, X. K. (2013). The Effect of Watershed Scale on HEC-HMS Calibrated Parameters: A Case Study in the Clear Creek Watershed in Iowa, US. Hydrology and Earth System Sciences, 17, 2735-2745. https://doi.org/10.5194/hess-17-2735-2013

\section{NOTATIONS}

Variables and functions

$A$ - average daily traffic;

$\mathrm{CN}$ - curve number;

$C_{1}$ - unit rebuilding cost;

$C_{3}$ - unit value of time per adult;

$C_{2}$ - unit cost of running vehicle;

$C_{4}$ - unit value of time per truck;

$D$ - detour length;

$d$-duration of detouring;

$E R$ - effective rainfall;

e - natural logarithm constant;

$I_{\mathrm{a}}$ - initial abstraction;

$K$ - risk adjustment factor;

$k$-storage coefficient;

$L_{\mathrm{b}}$ - bridge length;

$L_{\Omega}$ - length of main channel;

$M$ - cost multiplier to replace bridge after scour failure;

$n$ - number of successive linear reservoirs;

$O$ - occupancy rate;

$P$ - precipitation;

$P_{\mathrm{A}}-$ annual probability of scour failure; 
$P_{\mathrm{TR}}-$ trial probability of scour failure;

$R$ - annual scour risk;

$R_{\mathrm{A}}$ - area ratio;

$R_{\mathrm{b}}$ - bifurcation ratio;

$R_{1}$ - length ratio;

$S$ - average detour speed;

$S_{\mathrm{s}}$ - potential maximum retention in soil;

$T$ - average daily traffic;

$t$ - time;

$u$ - ordinates of the hydrograph;

$v$ - velocity of peak flood discharge;

$W$ - bridge deck width;

$X_{90}-90$ th percentile mean time to scour failure;

$\Gamma$ - gamma function;

$a$ - explanation of the first variable;

$b$ - explanation of the second variable;

$c$ - explanation of the third variable, etc.

\section{ABBREVIATIONS}

COV - coefficient of variance;

Fac - flow accumulation;

FHwA - Federal Highway Administration;

$T_{\mathrm{r}}$ - time of return period;

US\$ - US Dollar. 